\title{
ANALISIS MANAJEMEN HUMAS DALAM UPAYA MENINGKATKAN PARTISIPASI MASYARAKAT TERHADAP LEMBAGA PENDIDIKAN
}

Nadila Rahmadanti

\section{PENDAHULUAN}

Manajemen yang penting di sekolah adalah manajemen hubungan masyarakat (humas), karena sekolah berada di tengah-tengah masyarakat dan selalu berhubungan dalam menjalin kerja sama yang pedagogis dan sosiologis yang menguntungkan kedua bela pihak. Hubungan masyarakat telah di fomulasikan dengan cara yang berbeda-beda tergantung pada lembaga atau organisasi yang membuat formulasi tersebut.

Berangkat dari titik tolak pemikiran ini maka perlu ada pengaturan hubungan antara sekolah dengan masyarakat. Piet A. Sahertian (1994 : 233) menjelaskan bahwa humas dengan sekolah adalah salah satu bagian dari subtansi administrasi pendidikan sekolah. Dengan adanya hubungan sekolah dengan masyarakat, sekolah dapat mengetahui sumber-sumber yang ada dalam masyarakat yang kemudian di daya gunakan untuk kepentingan kemajuan pendidikan anak di sekolah. Di pihak lain, masyarakat juga dapat mengambil manfaat dengan turut mengenyam dan menyerap ilmu pengetahuan sekolah. Dari sini kehidupan masyarakat akan di tingkatkan. Oleh karenanya, masyarakat dapat mengerti dan memahami tujuan pendidikan dan pelaksanaan pendidikan yang berlangsung di sekolah tersebut.

Memang tidak bisa di pungkiri bahwa masyarakat dan sekolah mempunyai keterkaitan dan saling berperan satu sama lain. Apalagi pada zaman sekarang ini, pemerintah telah mensosialisasikan adanya desentralisasi pendidikan dimana sekolah mempunyai hak untuk mengatur sekolahnya sendiri. Oleh sebab itu smp negeri satap 9 bulukumba berusaha mengfungsikan dan mengatur manajemen humasnya dengan berusaha menjalin hubungan dengan masyarakat dan lembaga-lembaga lain di luar sekolah dalam rangka meningkatkan mutu pendidikannya. Muhammad Noor Syam dalam Made pidarta (1988 : 188), hubungan masyarakat dengan pendidikan sangat bersifat korelatif, bahkan seperti ayam dengan telurnya. Masyarakat maju karena pendidikan, dan pendidikan yang maju hanya akan di temukan dalam masyrakat yang maju pula.

Salah satu jalan masuk yang terdekat menuju peningkatan mutu dan relevansi adalah demokratisasi, partisipasi dan akuntabilitas pendidikan. Kepala sekolah, guru dan masyrakat adalah pelaku utama dan terdepan dalam penyelenggaraan pendidikan di sekolah sehingga segala keputusan mengenai penanganan persoalan pendidikan harus di hasilkan dari interaksi ketiga pihak tersebut. Masyarakat adalah stakeholder pendidikan yang memiliki kepentingan akan keberhasilan pendidikan di sekolah, 
karena mereka adalah pembayar pendidikan, baik melalui uang sekolah maupun pajak, sehingga sekolah sekolah seharusnya bertanggung jawab terhadap masyarakat.

Untuk itu hubungan masyarakat sangat penting dalam kepentingan organisasi sekolah, jadi jelas bahwa hubungan masyarakat terdapat suatu usaha untuk mewujudkan suatu hubungan yang harmonis antara sekolah dengan masyarakat sehingga akan muncul opini masyarakat yang menguntungkan bagi kehidupan sekolah tersebut.

Berdasarkan latar belakang diatas maka masalah yang akan diangkat dalam penelitian ini adalah:

"Seperti apa manajemen humas dalam upaya meningkatkan partisipasi masyarakat terhadap lembaga pendidikan SMP Negeri Satap 9 Bulukumba?"

\section{B. TINJAUAN PUSTAKA}

\section{Hubungan Lembaga Pendidikan Sekolah Dan Masyarakat}

\section{a) Pengertian Lembaga Pendidikan Sekolah}

Lembaga pendidikan sekolah adalah sub-sub sistem dari sistem pendidikan, yang terdiri atas beberapa unsur yang fungsional saling terkait antara satu dengan yang lainnya. Di dalam sejarah pendidikan di kemukakan bahwa sejak zaman pendidikan china kuno dan yunani kuno telah dijumpai adanya sekolah sebagai lembaga pendidikan. Perkataan "sekolah" berasal dari perkataan yunani :schola" yang artinya waktu nganggur atau waktu senggang. Bangsa yunani kuno mempunyai kebiasaan menggunakan waktu senggannya untuk berdiskusi guna menambah ilmu dan mencerdaskan akal. Lambat laun usaha tersebut diselenggarakan secara teratur dan terencana (secara formal), sehingga akhirnya timbullah sekolah sebagai lembaga pendidikan formal yang bertugas untuk menambah ilmu pengetahuan dan kecerdasan akal. Suwarno (1988: 70).

\section{b) Tujuan Lembaga Pendidikan Sekolah}

Berbicara tentang tujuan lembaga pendidikan sekolah, maka tidak lepas dari tujuan pendidikan nasional itu sendiri, dimana tujan pendidikian nasional berdasarkan pancasila dan undang-undang dasar 1945.

Lembaga pendidikan sekolah sesuai dengan pendidikan nasional berfungsi mengembangkan kemampuan dan membentuk watak serta peradaban bangsa, serta bertujuan untuk berkembangnya potensi peserta didik agar menjadi manusia yang beriman dan bertakwa kepada Tuhan Yang Maha Esa, berakhlak mulia, sehat, berilmu, cakap, kreatif, mandiri, dan menjadi warga negara yang demokratis serta bertanggung jawab. (Undang-Undang Republik Indonesia Nomor 20 Tahun 2003 : 7). Hal ini berarti lembaga pendidikan sekolah mempunyai tujuan untuk mengembangkan 
semua potensi yang di miliki manusia yaitu mulai dari tahapan kognisi, yakni pengetahuan dan pemahaman siswa terhadap ajaran agama dan pengetahuan umum, untuk selanjutnya di lanjutkan dengan tahapan efeksi, yaitu terjadinya proses internalisasi ajaran, nilai agama dan pengetahuan ke dalam diri siswa, dalam arti menghayati dan meyakini.

\section{c) Tugas Lembaga Pendidikan Sekolah}

Lembaga pendidikan sekolah seperti halnya lembaga pendidikan lainnya merupakan lembaga pendidikan kedua setelah keluarga. Tugas lembaga pendidikan pada intinya adalah sebagai wadah untuk memberikan pengarahan, bimbingan dan pelatihan agar manusia dengan segala potensi yang di milikinya (jasmani dan rohani) yang di berikan Tuhan Yang Maha Esa dapat di kembangkan dengan sebaik-baiknya.

d) Hubungan Lembaga Pendidikan Sekolah Dengan Masyarakat

Menurut finc dalam Made pidarta, (1995 : 127) mengatakan bahwa pendidikan harus merupakan bagian dari masyarakat. Sebab program tenaga kerja di ambil dari masyarakat juga dukungan dana dan tempat bekerja. Karenanya sekolah dan masyarakat harus memiliki keterkaitan yang erat. Esensi hubungan lembaga pendidikan dengan masayarakat adalah untuk meningkatkan keterlibatan, kepemilikan dan dukungan dari masyarakat terutama dukungan moral dan finansial. Dalam arti yang sebenarnya hubungan lembaga pendidikan sekolah dengan masyarakat adalah untuk menjalin kerja sama danbersam-sama bertanggung jawab terhadap keberhasilan dan kemajuan pendidikan, sehingga akan di butuhkan peningkatan intensitas dan ekstensitas hubungan lembaga pendidikan sekolah dengan masyarakat.

\section{Manajemen Hubungan Masyarakat}

Pada dasarnya, humas (hubungan masyarakat) merupakan bidang atau fungsi tertentu yang diperlukan oleh setiap organisasi, baik organisasi yang bersifat komersil (perusahaan) maupun organisasi yang non komersil. Mulai dari yayasan, perguruan tinggi, dinas militer sampai dengan lembaga-lembaga pemerintah. Kegiatan humas (public relation) pada hakekatnya adalah komunikasi. (M.Linggar Anggoro, 2000 : 12).

Komunikasi menurut Onong Uchjana (1986 : 4), adalah penyampaian suatu pesan oleh seseorang kepada orang lain untuk memberi tahu atau mengubah sikap, pendapat atau perilaku, baik langsung secara lisan maupun tidak langsung (melalui media). Namun komunikasi dalam humas berbeda dengan jenis kegiatan komunikasi lainnya. Kegiatan komunikasi dalam public relation mempunyai ciri-ciri tertentu, disebabkan karena fungsi sifat organisasi dari lembaga dimana public relation itu berada dan berlangsung, sifat-sifat manusia yang terlibat, publik yang menjadi sasaran dan factor factor eksternal yang mempengaruhinya. Ciri hakiki dari komunikasi dalam 
humas (public relation) adalah komunikasi yang bersifat timbal balik (two way traffic).

Komunikasi seperti ini ditujukan untuk menciptakan saling pengertian dan dukungan bagi terciptanya tujuan, kebijakan dan tindakan lembaga tersebut.

\section{Upaya Humas Dalam Membangun Hubungan Dengan Masyarakat}

Tanpa bantuan dari masyarakat, sebuah lembaga pendidikan tidak dapat

berfungsi dengan baik dan tanpa adanya program yang baik maka lembaga pendidikan akan gagal mencapai tujuannya. Oleh karena itu, lembaga pendidikan perlu memberikan informasi pada masyarakat tentang lembaga tersebut dengan cara yang baik. M. Amin Nur, (2006 : 216-219), ada beberapa tekhnik dalam berhubungan dengan masyarakat dalam lembaga pendidikan antara lain:

a. Laporan perkembangan peserta didik pada orang tua

b. Majalah sekolah

c. Surat kabar sekolah

d. Pameran kondisi dan kegiatan sekolah

e. Open house (Keterbukaan sekolah)

f. Kunjungan wali murid ke sekolah saat pelajaran di berlansung

g. Kunjungan ke rumah murid

h. Penjelasan personel sekolah

i. Profil sekolah melaui kreasi murid

j. Laporan tahunan k. Organisasi perkumpulan alumni sekolah

1. Kegiatan ekstra kurikuler

m. Pendekatan secara akrab.

\section{Hasil - Hasil Manajemen Humas di Lembaga Pendidikan Sekolah}

Untuk mengetahui berhasil atau tidaknya pelaksanaan humas di lembaga

pendidikan maka ada beberapa bentuk dan sifat partisipasi masyarakat yang dijadikan alat untuk mengukur keberhasilan program humas di sekolah. Menurut UndangUndang Republik Indonesia Nomor 20 Tahun 2003, tentang sistem pendidikan nasional :

Pasal 8 : Masyarakat berperan serta dalam perencanaan, pelaksanaan, pengawasan, dan evaluasi program pendidikan.

Pasal 9 : Masyarakat berkewajiban memberikan dukungan sumber daya dalam penyelenggaraan pendidikan. (Undang-Undang Republik Indonesia Nomor 20, $2003: 9)$

Pasal 54 : Ayat (1) Peran serta masyarakat dalam pendidikan meliputi peran serta perseorangan, kelompok, keluarga, organisasi profesi, pengusaha dan organisasi kemasyarakatan dalam penyelenggaraan dan pengendalian mutu pelayanan pendidikan.

: Ayat (2) Masyarakat dapat berperan serta sebagai sumber, pelaksana dan penggunaan hasil pendidikan. (Undang-Undang Republik Indonesia Nomor 20, $2003: 28)$. 


\section{Kerangka Konseptual}

Hubungan masyarakat sangat penting dalam kepentingan suatu organisasi sekolah, jadi jelas bahwa public relation terdapat suatu usaha untuk mewujudkan suatu hubungan yang harmonis antara sekolah dengan masyarakat sehingga akan muncul opini masyarakat yang menguntungkan bagi kehidupan sekolah tersebut.

\section{METODE PENELITIAN}

Penelitian ini adalah penelitian kualitatif yang bersifat deskriptif yakni penelitian yang berusaha menyajikan data, menganalisis dan menginterpretasi untuk menuturkan pemecahan masalah yang ada sekarang berdasarkan data.

Sumber data yang digunakan yakni data primer, seperti wawancara, hasil observasi, dan dokumen tertulis yang ada pada objek penelitian dan data sekunder, seperti sumber buku, majalah, arsip, ataupun dokumen resmi yang terkait dalam pembahasan penelitian ini. Tehnik pengolahan dan analisis data yaitu dengan melakukan library research dan field research setelah itu reduksi data, penyajian data, lalu verifikasi yaitu penarikan suatu kesimpulan.

\section{HASIL PENELITIAN DAN PEMBAHASAN}

1. Analisis Manajemen Humas Dalam Upaya Meningkatkan Partisipasi Masyarakat Terhadap Lembaga Pendidikan SMP Negeri Satap 9

Bulukumba Berdasarkan hasil penelitian yang di lakukan di SMP Negeri Satap 9 Bulukumba di ketahui dari hasil wawancara dengan kepala sekolah, Syamsuddin bahwa :

"Dalam membangun hubungan dengan masyarakat SMP Negeri Satap 9

Bulukumba menggunakan berbagai macam cara teknik komunikasi baik secara lisan, tulisan, campuran maupun secara perbuata (uswah hasanah). Hal itu perlu dilakukan agar pesan yang disampaikan dapat lebih menyebar dan di terima dengan baik oeh masyarakat yang relatife majemuk dari segi latar belakang pendidikan, tingkat ekonomi ataupun strata sosial. Sedangkan dalam penggunaan media SMP Negeri Satap 9 Bulukumba sangat memperhitungkan aspek keefektifan dan keefisienan". Selain itu ada beberapa upaya yang di tempu oleh SMP Negeri Satap 9 Bulukumba dalam meningkatkan partisispasi masyarakat terhadap pendidikan yang akan dijelaskan sebagai berikut;

a. Pemasagan spanduk pendaftaran, Program ini diadakan kareana masyarakat sekitar kurang mengetahui tentang hal-hal yang berkaitan dengan pendaftaran siswa baru baik yang berkenaan dengan waktu, biaya dan persyaratan-persyaratan yang harus di penuhi.

b. Pertemuan wali murid dengan guru dan pengurus sekolah. Berpijak pada pengertian tersebut bahwa pendidikan bukan hanya tanggung jawab sekolah semata, tetapi juga terdapat pendidikan keluarga dan pendidikan oleh masyarakat, ketiga unsur tersebut tidak dapat dipisahkan antara satu dengan lainnya. 
c. Program peningkatan kualitas bidang kehumasan, program ini bertujuan untuk lebih membekali tenaga humas dengan keterampilan dan wawasan yang lebih luas tentang humas, sehingga nantinya dapat di peraktekkan untuk peningkatan mutu pendidikan di SMP Negeri Satap 9 Bulukumba, kegiatan-kegiatan yang diikuti antara lain seminarseminar kewiraswastaan, mengadakan kunjungan-kunjungan perbandingan dan kegiatan lainnya.

Fungsi manajemen hubungan masyarakat (Humas) Dalam meningkatkan partisipasi masyarakat terhadap pengembangan pendidikan di SMP Negeri Satap 9 Bulukumba di implementasikan dalam perencanaan program humas yang menjadi agenda SMP Negeri Satap 9 Bulukumba dalam meningkatkan partisipasi masyarakat, sebagaimana di jelaskan oleh Hariani selaku Humas SMP Negeri Satap 9 Bulukumba.Beliau mengungkapkan bahwa:

"Perencanaan yang menjadi program rutin humas terkait dengan partisipasi masyarakat adalah dengan melibatkan Komite Sekolah dalam perencanaan program pendidikan di sekolah. Perencanaan rapat koordinasi pengurus Komite Sekolah dalam mengesahkan Rencana Anggaran Pendapatan dan Belanja Sekolah (RAPBS). Perencanaan pengumpulan zakat fitrah siswa kerja sama dengan Dewan sekolah dan Dinas Pendidikan, perencanaan penyampain informasi perkembangan siswa dan sekolah kepada orang tua siswa yang dilaksanakan setiap akhir semester".

Rencana kegiatan yang disebutkan diatas merupakan rangkaian kegiatan yang melibatkan partisipasi masyarakat dalam program kegiatan pendidikan di SMP Negeri Satap 9 Bulukumba. sebagaimana yang di tambahkan oleh Muh. Tahir selaku wakepsek SMP Negeri Satap 9 Bulukumba beliau mengungkapkan bahwa : "perencanaan program humas yang senantiasa kami siapkan secara rutin setiap tahunnya, yaitu silaturahmi dengan orang tua siswa kelas 7 pada awal tahun ajaran dan sosialisasi program sekolah, kunjungan sosial terhadap orang tua yang mendapat musibah bersifat incidental, kunjungan ke kelompok belajar di rumah siswa, bakti sosial terhadap para kelurga miskin dilaksanakan oleh siswa kelas 9 menjelang pelaksanaan UAN (Ujian Akhir Nasional), bakti sosial terhadap masyarakat dilaksanakan pada waktu hari-hari besar agama atau hari-hari besar nasional, halal bi halal denagn keluarga besar sekolah, peringatan hari-hari besar keagamaan bersama masyarakat, dan penyampaian informasi siswa bermasalah pada orang tua siswa disesuaikan denagn kondisi waktu yang dibutuhkan”. Perencanaan program Humas yang di agendakan oleh SMP Negeri Satap 9 Bulukumba diharapkan dapat terealisasi dengan harapan bahwa pada saat pelaksanaannya masyarakat benar-benar dapat berpartisipasi, sehingga peran masyarakat dalam pengembangan dan pengelolaan pendidikan di SMP Negeri Satap 9 Bulukumba semakin nyata dan semaking meningkat. Pelaksanaan Manajemen humas di SMP Negeri Satap 9 Bulukumba lebih pada 
usaha menggiatkan program kerja yang melibatkan partispasi masyarakat agar benarbenar

tumbuh kesadaran dan rasa kepemilikan masyarakat untuk terus aktif berperan dalam meningkatkan mutu pendidikan dan untuk mencapai kesuksesan program humas di

sekolah adalah tanggung jawab bersama dan kemauan setiap personil yang telah diberikan tugas dalam melaksanakan kewajibannya. Dan yang paling bertanggung jawab pada semua kegiatan pendidikan adalah pemimpin seorang pemimpin harus mampu memotivasi setiap anggotanya untuk bekerja denagn penuh semangat, agar tujuan yang diharapkan terhadap kegiatan tersebut dapat tercapai dengan baik.

Sebagaimana yang di ungkapkan oleh KTU SMP Negeri Satap 9 Bulukumba Risman menjelaskan bahwa :

"kesuksesan dari pelaksanaan program humas sekolah, tidak dapat dipisahkan dari kemampuan seorang pemimpin dalam mengelolah sistem kerja para anggotanya. Pemimpin harus mampu mengkoordinir setiap personil agar dapat menyelesaikan setiap pekerjaan sesuai dengan jadwal yang telah ditetapkan dan selalu mensinkronkan dengan kegiatan-kegiatan yang lainnya. Seorang pemimpin mampu menanamkan semangat dalam diri para anggota untuk mengerahkan segala kemampuannya, guna mencapai tujuan dari kegiatan kehumasan tersebut.”

\section{E. KESIMPULAN}

Dari hasil penelitian yang telah dilakukan dan dijelaskan dalam pembahasan, maka ditarik kesimpulan bahwa upaya SMP Negeri Satap 9 Bulukumba dalam membangun hubungan dengan masyarakat merujuk pada teknik komunikasi baik secara lisan, tulisan maupun secara perbuatan (uswah hasanah). Hal itu perlu di lakukan agar pesan yang disampaikan dapat lebih menyebar dan di terima dengan baik oleh masyarakat yang relatif majemuk dari segi latar belakang pendidikan, tingkat ekonomi ataupun strata sosial sedangkan dalam penggunaan media SMP Negeri Satap 9 bulukumba sangat memperhitungkan aspek keefektifan dan keefisienannya yang kemudian di implementasi secara spesifik sebagai berikut :

1. Pelibatan Komite sekolah dalam menyusun rencana program sekolah dan perencanaan kegiatan pengumpulan zakat fitrah oleh sekolah.

2. Perncanaan program penyampaian informasi perkembangan siswa dan sekolah kepada orang tua siswa yang dilaksanakan setiap akhir semester.

3. Perencanaaan program silaturahmi dengan orang siswa kelas 7 pada tahun ajaran dan sosialisasi program sekolah kepada masyarakat.

4. Perencanaan program kunjungan sosial terhadap orang tua yang mendapat musibah, kunjungan ke kelompok belajar di rumah siswa.

5. Perencanaan program bakti sosial terhadap para keluarga miskin dilaksanakan oleh siswa kelas 9 menjelang peleksanaan UAN (ujian akhir nasional).

6. Perencanaan program bakti sosial terhadap masyarakat dilaksanakan pada waktu hari-hari besar agama atau hari-hari besar nasional.

7. Perencanaan program halal bi halal denagn keluarga besar sekolah. 
8. Perencanaan program peringatan hari-hari besar keagamaan bersama masyarakat. 9. Perencanaan program penyampaian informasi siswa bermasalah pada orang tua siswa.

Pelaksanaan Manajemen humas di SMP Negeri Satap 9 Bulukumba lebih pada usaha menggiatkan program kerja yang melibatkan partispasi masyarakat agar benarbenar tumbuh kesadaran dan rasa kepemilikan masyarakat untuk terus aktif berperan dalam meningkatkan mutu pendidikan dan untuk mencapai kesuksesan program humas disekolah adalah tanggung jawab bersama dan kemauan setiap personil yang telah diberikan tugas dalam melaksanakan kewajibannya. Dan yang paling bertanggung jawab

pada semua kegiatan pendidikan adalah pemimpin seorang pemimpin harus mampu memotivasi setiap anggotanya untuk bekerja denagn penuh semangat, agar tujuan yang diharapkan terhadap kegiatan tersebut dapat tercapai dengan baik. 


\section{SOAL DAN LATIHAN}

\section{Pilihan ganda}

1. Salah satu jalan masuk yang terdekat menuju peningkatan mutu dan revisi adalah...

a. Demokratisasi, partisipasi dan akuntabilitas pendidikan

b. Akuntabilitas pendidikan

c. Mengatur sekolah sendiri

d. Administrasi pendidikan sekolah

2. Penelitian kualitatif yang bersifat deskiptif yakni penelitian yang berusaha menyajikan data adalah...

a. Mewujudkan suatu hubungan yang harmonis

b. Pelaksanaan yang menggunakan hasil penelitian

c. Menganalisis dan menginterpertasi untuk menuturkan pemecahan masalah yang ada sekarang berdasarkan data

d. Wawancara hasil observasi

3. Hubunga lembaga pendidikan sekolah dengan masyarakat adalah...

a. Lembaga-lembaga pemerintahan

b. Pendidikan dan sekolah harus memiliki keterkaitan yang kuat

c. Komunikasi dan humas

d. Karena sekolah dan masyarakat harus memiliki keterkaitan yang erat

4. Apa tujuan lembaga pendidikan sekolah...

a. Untuk berkembangnya potensi peserta didik agar menjadi manusia yang beriman dan bertakwa kepada Tuhan Yang Maha Esa

b. Agar masyarakat dan pendidikan ada komunikasi

c. Untuk meningkatkan kualitas pendidikan

d. Untuk meningkatkan kualitas tenaga pendidik

5. Tugas lembaga pendidikan adalah untuk...

a. Untuk pendidikan dan pengertahuan peserta didik

b. Untuk masyarakat agar berfungsi dengan baik

c. Sebagai wadah untuk memberikan pengarahan, bimbingan dan pelatihan

d. Agar pendidik lebih berkomunikasi

6. Ciri hakikat komunikasi dari humas adalah...

a. Komunikasi yang verbal

b. Kegiatan ekstra kulikuler

c. Laporan perkembangan peserta didik pada orang tua

d. Komunikasi yang bersifat timbal balik 
7. Kerangka konseptual dengan masyarakat adalah...

a. Akan muncul opini masyarakat yang menguntungkan bagi sekolah tersebut

b. Masyarakat berperan serta dalam pendidikan

c. Masyarakat berperan sebagai sumber atau pelaksanaan

d. Penelitian masyarakat

8. Apa undang-undang tentang system pendidikan nasional pasal $8 \ldots$
a. Menganalisis dan menginterpretasi
b. Menyajikan data
c. Masyarakat berperan serta dalam perencanaan pelaksanaan, pengawasan, dan evaluasi program pendidikan
d. Masyarakat berperan dalam pendidikan sekolah

9. Apa hubungan lembaga pendidikan dengan masyarakat menurut Finc dalam Made Pidarta...
a. Pendidikan dan organisasi yang bersifat komersil
b. Pendidikan harus merupakan bagian dari masyarakat
c. Pendidikan harus berkomunikasi dengan masyarakat
d. Pendidikan dan masyarakat yang formal

10. Apa menurut M Amir Nur tentang pendidikan...
a. Lembaga pendidik perlu memberikan informasi pada masyarakat tentang lembaga tersebut dengan cara yang baik
b. Komunikasi dengan humas berbeda jenis dengan kegiatan komunikasi lainnya
c. Manajemen hubungan masyarakat
d. Organisasi non komersil

\section{Esai}

1. Manajemen yang penting di sekolah adalah manajemen humas. Kenapa?

2. Apa pengertian lembaga pendidikan sekolah?

3. Sebutkan beberapa teknik dalam berhubungan dengan masyarakat dalam lembaga pendidikan?

4. Apa komunikasi menurut onong uchjana?

5. Apa esensi hubungan lembaga pendidikan dengan masyarakat? 


\section{Jawaban}

\section{Pilihan ganda}

1. a) Demokratisasi, partisipasi dan akuntabilitas pendidikan

2. b) Menganalisis dan menginterprestasi untuk menuturkan pemecahan masalah yang ada sekarang berdasarkan data

3. d) Karena sekolah dan masyarakat harus memiliki keterkaitan yang erat

4. a) untuk berkembangnya potensi peserta didik agar menjadi manusia yang beriman dan bertakwa kepada Tuhan Yang Maha Esa

5. c) sebagai wadah untuk memberikan pengarahan, bimbingan dan pelatihan

6. d) Komunikasi yang bersifat timbal balik

7. a) Akan muncul opini masyarakat yang menguntungkan bagi kehidupan sekolah tersebut

8). c) Masyarakat berperan serta dalam perencanaan, pelaksanaan, pengawasan dan evaluasi program pendidikan

9. b) Pendidikan harus merupakan bagian dari masyarakat

10. a) Lembaga pendidik perlu memberikan informasi pada masyarakat tentang lembaga tersebut dengan cara yang baik

\section{Esai}

1. Karena sekolah berada di tengah-tengah masyarakat dan selalu berhubungan dalam menjalin kerjasama yang pedadogis dan sosilogis yang menguntungkan kedua belah pihak.

2. Lembaga pendidikan sekolah adalah sub-sub sistem dari sistem pendidikan, yang terdiri atas beberapa unsur yang fungsional saling terkait antar satu dengan yang lainnya.

3. a) majalah sekolah

b) surat kabar sekolah

c) kunjungan kerumah murid

d) penjelasan personel sekolah dll

4. Adalah penyampaian suatu pesan oleh seseorang kepada orang lain untuk memberi tahu atau mengubah sikap, pendapat atau perilaku, baik langsung secara lisan maupun tidak langsung (melalui media).

5. Adalah untuk meningkatkan keterlibatan, kepemilikan dan dukungan dari masyarakat terutama dukungan moral dan finansial. 


\section{DAFTAR PUSTAKA}

Made Pidarta, Manajemen Pendidikan Indonesia, (Jakarta:PT Bina Aksara, 1988), hal 188.

--------------- Peranan Kepala Sekolah Pada Pendididkan Dasar (Jakarta: Gramedia Widiasarana, 1995), hal 127.

M. Amin Nur, Strategi Meningkatkan Mutu Pendidikan Melalui Pemberdayaan Masyarakat

(Fakultas Tarbiyah UIN Malang: El Hikmah, 2006), hal. 216-219.

M. Linggar Anggoro, Teori Dan Profesi Kehumasan Serta Aplikasinya di Indonesia (Jakarta: Bumi Aksara, 2000). hal 1-2.

Onang Uchjana, Dinamika Komunikasi (Bandung: CV. Remaja Karya, 1986), hal 4.

Piet A. Sahertian, Dimensi Administrasi Pendidikan (Surabaya: Usaha Nasional, 1994), hal

223.

Suwarno, Penagantar Umum Pendidikan (Jakarta: Bina Aksara, 1988), hal 70. 